\title{
Barriers to Effective use of Information Technology in Science Education at Yanbu Kingdom of Saudi Arabia
}

\author{
Abdulkareem Eid S. Alwani and Safeeullah Soomro \\ Emails:aalalwani@ieee.org, safee@ieee.org \\ Yanbu University College \\ Yanbu-Al Sinaiyah, Yanbu \\ Kingdom of Saudi Arabia
}

\begin{abstract}
This study examined the barriers to use of information technology (IT) in science education at the Yanbu school district in Saudi Arabia. Sub-domains investigated included: infrastructure and resources, policy and support, science teachers' personal beliefs, and staff development. This chapter is using a survey which shows common barriers encountered by the science teachers were identified. Demographic data enabled description of science teachers based on similarities and differences of gender, location of the school, training, years of teaching experience, and age. Science teachers rated the barriers limiting their use of technology in teaching on a scale ranging from 0 (does not limit) to 3 (greatly limits). We present results which showed that all four domains were highly significant barriers: infrastructure and resources $(\mathrm{M}=2.06, \mathrm{p}<.001)$; staff development $(\mathrm{M}=2.02, \mathrm{p}<.001)$; policy and support $(\mathrm{M}=1.84, \mathrm{p}<.001)$; and science teachers' personal beliefs regarding technology $(\mathrm{M}=1.15, \mathrm{p}<.001)$. The more bariers comes to face the teachers who are related to science and are experienced, the less likely they were to be IT users $(r=-0.16, p=.02)$. To minimize the impact of these barriers and consequently improve the level of integration of information technology in science education in Saudi Arabia, a well-conceived strategic vision, adequate funding, and good implementation plan are of great importance.
\end{abstract}

\section{Introduction and Related Research}

Day after day, the importance of information technology becomes more evident and requires more of our attention. Today's world is one full of information. Through the use of information technology and the Internet, information is now more accessible than ever before. We are swamped with information and increasingly derive knowledge gained from information distributed by the Internet, newspapers, television, computers, magazines, books, radio, etc. Information technology penetrates every corner of our world and our 
individual lives. What does that mean to us? How can we evaluate the legitimacy of the new "information technology era" and realize its promise of greater knowledge for the many?

The World Wide Web makes our world so small that it increasingly resembles a small village. Internet users tend to know what is going on in their cyber-neighbors' lives; even when that neighbor is often living on the other side of the world! According to Becta (2003) and (Samman, 2003), new technologies might improve our lives in two ways: a) by enabling us to do things better, and b) by enabling us to do better things. Information technologies today significantly affect every society in the world, especially in the field of education.

Successful integration and/or adoption of information technology as well as its rejection depend on several factors. These factors could vary from one place to another depending on the environment where the technology is introduced as well as the purpose and timing of the introduction. Several studies have been conducted on this regard.

The purpose of this study was to examine the barriers that prevent science teachers from Yanbu education district in Saudi Arabia from using information technology in their teaching. This study investigated the degree of IT use and examined the barriers to its use in teaching science.

What are the unique barriers encountered by Saudi educators in the transition to ITfacilitated education? This study outlined an investigation into the barriers that prevent effective use of IT in science education in K-12 public schools in Saudi Arabia, specifically drawing from the perspectives of science teachers. Two research questions were considered:

1. Do science teachers encounter common barriers that prevent them from making effective use of IT in science education in the public schools at the Yanbu education district in Saudi Arabia? And

2. Do science teachers encounter unique barriers (other than the common barriers identified in the first research question) that may prevent them from making effective use of IT in science education in Saudi Arabia?

Weber (1996) surveyed three major themes related to IT barriers: (a) inadequate instruction; (b) inadequate computer systems; and (c) frustration. Examples of barriers that Weber identified include lack of administrative support, financial constraints, policy confusion, logistic limitations, conflicting purchasing decisions, support service deficiencies, and untrained personnel. In addition, he categorized groups of barriers to the use of technology that many researchers have also identified. These are: (a) anxiety; (b) stress; (c) feelings of stupidity, fear of the unfamiliar, and fear of dehumanizing effects; (d) the extreme of computer addiction (microcomputer mania); and (e) the extreme of computer phobia (cyberphobia), potentially involving active resistance, and sabotage.

Beggs (2000) posited that one critical barrier pertains to science teachers' poor preparation and lack of confidence related to IT. While there is some evidence of a history of using technology in science classrooms, not all science teachers are ready to use IT in teaching science. Some instructors, even those well educated and highly competent in the field of science, have been documented as fearing technology, most particularly fearing looking 
stupid in front of their students by failing in their use of IT. Fear of failure is a very legitimate problem. Ertmer (1999) pointed out that many teachers may ask themselves a hard-to-answer question: "What will I do if the technology fails and I can't complete the lesson as planned?" This may interfere with the adoption of technology in the classroom. Logically, to the extent that teacher training and technical support can answer teachers' questions of what happens when technology does not work, this barrier is reduced.

The U.S. Congressional report as cited in Corbin (2003) reported that the Office of Technology Assessment (OTA) suggested that the lack of experience using technology in the student teaching experience was a major concern. This report goes on to say that to overcome this problem, "K-12 and university educators must work together to integrate technology in the curriculum" (U.S. Congress, 1995, p. 165). Therefore, it is fair to say that the modest level of IT skills in teachers has been a barrier in its implementation in both education in general, and in science education, in particular (Corbin, 2003).

Al-Mohaissin (1993) listed some barriers that prevent effective use of IT in science teaching. The barriers he identified included the fact that poor consistency and compatibility existed between teacher training, available software, and hardware in schools. Most efforts undertaken were to supply hardware. However, the hardware that was delivered to Saudi schools was very limited; consisting of older and limited versions. The hardware installed supported very limited software applications produced by the hardware company. Often, this software did not serve the needs of the science teachers. There is a lack of availability of Arabic computer software for science and what is available is very expensive. Al-Mohaissin did not consider lack of funding a barrier but he indicated that lack of knowledge about IT at the purchasing level resulted in the performance and compatibility barriers experienced. He suggested generic software, like Word and Excel, to overcome the high price of the software programs.

Al-Oteawi (2002) found that there were not enough courses on IT in the colleges, particularly related to computer navigation and Internet skills. No programs existed in the colleges of education that allowed students to learn how to integrate IT in the curricula. Neither there were any in-service training programs in existence that permitted students and educators to develop their knowledge of IT processes.

According to the National Council for Accreditation of Teacher Education (NCATE, 1997), lack of training, knowledge, or familiarity leads to teachers' inability to independently integrate subject matter software with necessary computer hardware. A sizeable amount of literature exists that identifies overlapping barriers, lack of teacher knowledge, and inability to integrate hardware/software reliably. From this literature, a picture can be drawn of the perennial "vicious circle" that illustrates barrier relationships. Teachers' "fear of failure" is reinforced by failure to use IT successfully. The more a teacher internalizes previous failures, the less likely it is that he/she will be able to solve new compatibility issues. The more demands there are on teachers to make IT work in the classroom, the more fear of failure. These issues have implications for supporting science teachers in the IT implementation. 
Corbin (2003) identified five barriers and grouped them into three areas: lack of experience in pre-service training, lack of access to computers at school, and lack of on-site technical support. He also stated that the most important barrier most teachers must deal with is lack of access to computers, either in a laboratory setting or in the classroom.

After gathering information through online questionnaires of 170 teachers, Becta (2003) discussed barriers to IT adoption. Arranged from the most to least frequent, these barriers included: lack of confidence, lack of access to quality resources, lack of time, lack of effective training, technical problems, lack of personal access, and age.

Brush (2003), studied what teachers themselves think are the barriers to IT-related instruction. Nine barriers included in his survey were: lack of hardware, lack of software, lack of network access, lack of time to develop courses, lack of support by department or school, lack of salary support during the development period, lack of students' preparation to handle technology, lack of facilities for student laboratories, and lack of central resources.

Al-Moussa (2004) discussed the barriers to integration of IT within Gulf Cooperation Council (GCC) countries. They are: lack of teachers' training programs in the use of the computer, high cost of computer peripherals, and lack of computer technicians in the schools to help teachers and administrators apply IT.

The chapter is an organized as follows. In Section 2 we introduce our methodology which provides procedure to collect our data and shows the findings regarding barriers of IT education in Yanbu. In Section 3 we present the limitation of our analysis method. In Section 4 we present results and discussions. Finally we summarize the chapter with future discussion and recommendations.

\section{Methodology}

The study was conducted in Yanbu education district in Saudi Arabia. The research designs used were descriptive, comparative, and correlational. Both male and female science teachers at the elementary, middle, and high school levels were asked on their use of IT in the classroom. Comparisons of their survey responses were made. The relationship between demographic information and science teachers' computer experience to their attitudes toward computers was also determined.

The study examined and identified the barriers that hinder the inclusion of IT in science education in Saudi Arabia. The research instrument was developed to replicate this study at future time intervals to monitor trends and the degree of the technology use in Saudi Arabia over a period of time.

Based on the findings from a preliminary focus group of 80 science teachers in Saudi Arabia, common barriers to IT adoption were identified and used to design the survey instrument. 


\subsection{Variables}

There were three categories of variables in the study: (a) dependent variables, (b) demographic variables, and (c) independent variables. The dependent variables of this study were the scores related to degree and frequency of technology use. The instrument used scored measures of amount of technology use, skill levels, and conformity with technology.

The demographic variables came from questions included in the final segment of the survey. These questions include: (a) school location, b) participant's gender, (c) his/her years of teaching experience, (d) pre-service IT training, (e) in-service IT training, and (f) age.

The independent variables focused on four categories of barriers. Each category contained statements designed to test the frequency of the science teachers' responses to determine whether or not it should be considered a barrier. The four groups were: (a) infrastructure and resources, (b) policy and support, (c) science teachers' personal beliefs, and (d) staff development. Participants were asked to add any other barriers they considered important that were not mentioned in the instrument.

\subsection{Survey Instrument}

The survey consisted of two main parts. The first part investigated barriers to implementing IT in science education in public schools in Yanbu education district in Saudi Arabia. The second part focused on demographic factors.

The first part of the instrument consisted of four sections: (a) infrastructure and resources, (b) policy and support, (c) science teachers' beliefs, and (d) staff development. It also included barriers not previously mentioned in the instrument but added by study participants in response to an open-ended question. Participants evaluated each barrier and rated it according to the values defined in Table 1.

\begin{tabular}{|l|l|}
\hline Description & Value \\
\hline Does Not Limit & 0 \\
\hline Slightly Limits & 1 \\
\hline Somewhat Limit & 2 \\
\hline Greatly Limits & 3 \\
\hline
\end{tabular}

Table 1. Limitations of Technology Scale

The second part of the survey contained 12 elements of demographic information. They included: (a) schools' location, (b) gender, (c) years of teaching experience, (d) training, (e) age, (f) grade levels taught, (g) number of classes taught weekly, (h) highest educational degree and year earned, (i) presence of a computer in their home or school, (j) where computers were used (at home or school), (k) where access to the Internet was available (at home or school), and (l) number of computers available in teachers' classrooms and in computer laboratories in schools. 


\subsection{Participants/Respondents}

Study participants included teachers from all K-12 grade levels who were teaching during the School Year 2003-2004. According to the Department of Statistics (2003) in Yanbu Education District, there were a total of 284 science teachers in grades K-12. Survey questionnaires were sent to all schools at the Yanbu education district and distributed by the educational training department to all male and female science teachers who volunteered to participate in the study. Aboutb 176 questionnaires were returned back by 105 male and 71 female science teachers, constituting 60 percent and 40 percent of those solicited, respectively.

\subsection{Statistical Methods}

The first research question asked was "Do science teachers encounter common barriers that prevent them from effectively using IT in science education in the public schools at Yanbu education district in Saudi Arabia?" The null hypothesis for this question is: Science teachers do not encounter common barriers that prevent them from effectively using IT in science education in the public schools at the Yanbu education district in Saudi Arabia.

This was tested using the sample $t$-test. The domains were tested individually which include: (a) infrastructure and resources, (b) policy and support, (c) science teachers' personal beliefs, and (d) staff development (Table 2). In a Table 2 analysis the statistics and Intercorellation Matrix describing barriers to integration of IT in Science education in Yanbu School as indicated by frequency of IT use.

The average of all participants in every domain was derived. Arranged by perceived importance, the participants reported that most barriers were associated with infrastructure and resources, staff development, policy and support, and the teachers' personal beliefs. SPSS was used to calculate the $t$-statistic and its significance at .05 level.

\begin{tabular}{|l|l|l|l|l|l|l|l|l|}
\hline & \multicolumn{7}{|c|}{ Intercorrellation } \\
\hline Variable & Mean & SD & SEM & IT & IR & PS & PB & SD \\
\hline Frequency of use of IT and & 1.13 & .78 & & .88 & & & & \\
\hline $\begin{array}{l}\text { Infrastructure } \\
\text { Resources (IR) }\end{array}$ & 2.06 & .673 & .051 & $.04^{*}$ & .93 & & & \\
\hline Policy and Support (PS) & 1.84 & .696 & .052 & $-.18^{*}$ & $.48^{*}$ & .86 & & \\
\hline $\begin{array}{l}\text { Teachers' Personal Beliefs } \\
\text { (PB) }\end{array}$ & 1.15 & .682 & .052 & $-.20^{* *}$ & $.17^{*}$ & $.39^{* *}$ & .91 & \\
\hline Staff Development (SD) & 2.02 & .783 & .59 & $-.16^{*}$ & $.67^{* *}$ & $.77^{* *}$ & $.67^{* *}$ & .92 \\
\hline
\end{tabular}

Table 2. Descriptive Statistics and Intercorellation Matrix

Note: Cronbach's alpha scores of internal consistency are reported in diagonal of correlation matrix

*Significant at 05 level of significance

** Significant at .01 level of significance 
The second research question asked was, "Do science teachers encounter unique barriers (other than explicit barriers listed in the second research question) that may prevent them from effectively using IT in science education in Saudi Arabia?" All anticipated major barriers that may prevent science teachers from using IT were explicitly included in the survey. Acknowledging that important barriers may have been overlooked, an open-ended question was included to let the participants express their opinions and thoughts about barriers not mentioned in the survey. Analysis of their answers was conducted by calculating how many times each new barrier mentioned was repeated. After the data were collected, responses were summarized and classified based on location and gender.

\section{Limitation}

This study was focused only on science teachers from only one educational district covering School Year 2003-2004. Aspects of IT implementation can change over time. Based on the continuous evolutionary development of the computer industry, the degree of technology use this year may be different from that of next year.

This research was limited to a specific region in Saudi Arabia, the Yanbu district. It is hoped that these results could be generalized due to the inclusion of feedback from across Saudi Arabia which was used in the development of the survey instrument. However, one limiting factor of this research is that the results may not be generalized to non-science teachers. The barriers to the application of IT in other fields may be different from those in the field of science.

\section{Experimental Results and Discussions}

Barriers to IT Integration

Results of a one-sample t-test for all these subdomains of barriers to IT integration are reported in Table 3. All $\mathrm{p}$ values for the four subdomains are less than .05 indicating that these common barriers prevent science teachers from effectively using IT science education in the public schools in the Yanbu education district in Saudi Arabia.

\begin{tabular}{|l|l|l|l|}
\hline & $\boldsymbol{t}$ Value & Significance & Mean \\
\hline Infrastructure and Resources & 40.52 & $.000^{*}$ & 2.06 \\
\hline Policy and Support & 35.11 & $.000^{*}$ & 1.84 \\
\hline Science Teachers' personal belief & 22.36 & $.000^{*}$ & 1.15 \\
\hline Staff Development & 34.13 & $.000^{*}$ & 2.03 \\
\hline
\end{tabular}

Table 3. Limitations of Technology Scale

*Significant at 05 level of significance

Top ten barriers. To discern trends, specific common barriers were examined in terms of frequency of occurrence. Tables 4 and 5 show the top 10 and top five barriers by frequency of response, respectively. 


\begin{tabular}{|l|l|l|l|l|}
\hline$\#$ & Barrier & Mean & $\begin{array}{l}\text { Std. } \\
\text { Dev }\end{array}$ & $\begin{array}{l}\text { Sub- } \\
\text { Domain }\end{array}$ \\
\hline 1 & No Specific IT Budget & 2.48 & .88 & PS \\
\hline 2 & Lack of Finding for Hardware & 2.48 & .88 & PS \\
\hline 3 & No Electronic, Science Text Books & 2.31 & 1.01 & IR \\
\hline 4 & Lack of English Training needed for IT & 2.27 & .97 & SD \\
\hline 5 & Not enough Time in School for IT related activities & 2.26 & 1.06 & STPB \\
\hline 6 & $\begin{array}{l}\text { No instructional support for incorporating IT into } \\
\text { teaching }\end{array}$ & 2.24 & 1.13 & IR \\
\hline 7 & No vision or Strategic plan for IT & 2.23 & 1.01 & PS \\
\hline 8 & Science Curriculum not compatible with IT & 2.18 & 1.03 & IR \\
\hline 9 & No access to Internet during School & 2.18 & 1.12 & IR \\
\hline 10 & Classroom Architecture not suitable for IT & 2.17 & 1.09 & IR \\
\hline
\end{tabular}

Table 4. Top Ten Barriers that limit the Use of IT in Science Education at Yanbu, KSA

Note: Scale runs from "doecn't limit" (0) to "greatly limits". $N=176$.

Where

IR = Infrastructure and Resources

PS $=$ Policy and Support

$\mathrm{STPB}=$ Science Teachers ${ }^{\prime}$ Personal Beliefs

$\mathrm{SD}=$ Staff Development

Five least frequently cited barriers. There were five statements in the survey that most participants considered to be the least limiting barriers to IT use (Table 6).

The following summarizes the additional barriers as submitted by participants in response to the open-ended question. Most of their responses were focused on the following:

1. No information technology resource centers in education districts and in schools;

2. No specialist trainers to train teachers and students;

3. Busy schedules leave no time;

4. Teaching more than one subject;

5. Shortage of short courses (in-service training); and

6. High cost of short courses. 


\begin{tabular}{|c|c|c|c|c|c|c|}
\hline & $\begin{array}{l}\text { Does Not } \\
\text { Limit } \\
\end{array}$ & $\begin{array}{l}\text { Slightly } \\
\text { Limit }\end{array}$ & \multicolumn{2}{|c|}{$\begin{array}{l}\text { Somewhat } \\
\text { Limit }\end{array}$} & \multicolumn{2}{|c|}{$\begin{array}{l}\text { Greatly } \\
\text { Limit }\end{array}$} \\
\hline & $\begin{array}{l}\text { Freq } \\
\%\end{array}$ & $\begin{array}{l}\text { Freq } \\
\%\end{array}$ & Freq & $\%$ & Freq & $\%$ \\
\hline $\begin{array}{l}\text { No specific budget for } \\
\text { information technology } \\
\text { in my school (PS) }\end{array}$ & $\begin{array}{l}9 \\
5.1\end{array}$ & $\begin{array}{l}19 \\
10.8\end{array}$ & $\begin{array}{l}27 \\
15.3\end{array}$ & & 121 & 68.8 \\
\hline $\begin{array}{l}\text { The lack of school } \\
\text { funds to get hardware } \\
\text { (PS) }\end{array}$ & $\begin{array}{l}19 \\
10.08\end{array}$ & $\begin{array}{l}13 \\
7.4\end{array}$ & $\begin{array}{l}38 \\
21.6\end{array}$ & & 106 & 60.2 \\
\hline $\begin{array}{l}\text { Students don't have } \\
\text { access to the internet } \\
\text { during the school day } \\
\text { (IR) }\end{array}$ & $\begin{array}{l}25 \\
14.2\end{array}$ & $\begin{array}{l}21 \\
11.9\end{array}$ & $\begin{array}{l}28 \\
15.9\end{array}$ & & 102 & 58.0 \\
\hline $\begin{array}{ll}\text { The architecture } & \text { of } \\
\text { class rooms are not } \\
\text { suitable } & \text { for } \\
\text { implementing IT } & \\
\end{array}$ & $\begin{array}{l}23 \\
13.1\end{array}$ & $\begin{array}{l}22 \\
12.5\end{array}$ & $\begin{array}{l}33 \\
18.8\end{array}$ & & 98 & 55.7 \\
\hline
\end{tabular}

Table 5. Limitations to Technology integration imposed by Infrastructure and Resources

Note. Where $\mathrm{N}=176, \mathrm{IR}=$ Infrastructure and resources, PS = Policy and support, STPB = Science teachers' personal beliefs and SD = Staff Development

It was found that some male teachers from industrial locations and some male teachers from urban locations agreed about the following barriers that prevented them from effective applications of IT. They reported that there was no IT center in the education district or in their schools and there were no specialized and qualified trainers to train teachers and students to use IT in the right way.

Many of the female science teachers from industrial locations experienced the same barriers that male teachers from suburban locations have experienced. These barriers were: busy schedules, teaching more subjects, and doing some work besides teaching. All of these barriers prevent them from applying IT to educational practice. In addition, female teachers from industrial locations have encountered some of the same barriers as male teachers from urban locations, including the shortage of short-course training on how to implement IT into the science curriculum and the high cost they would incur if they choose to pay on their own. 


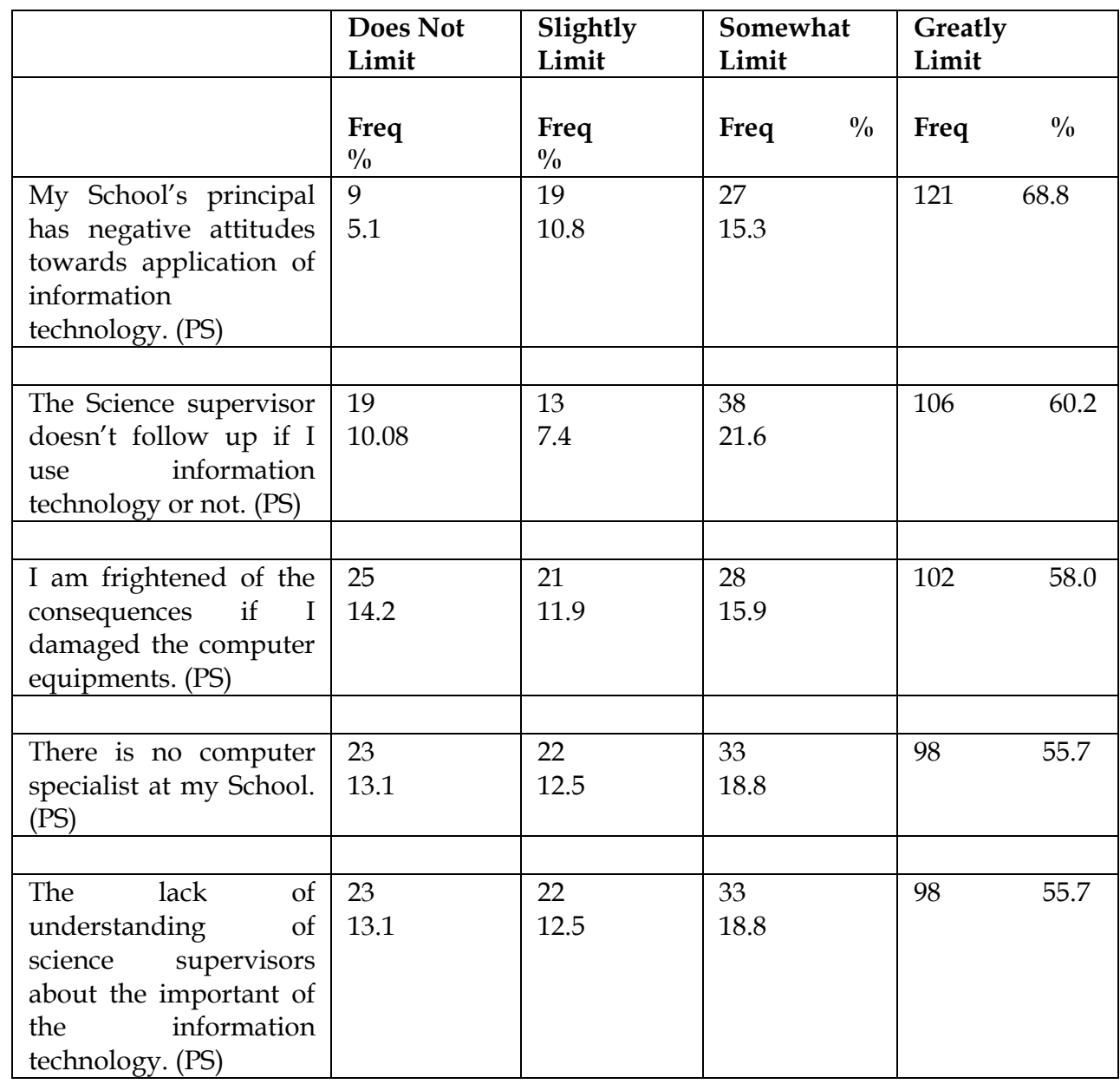

Table 5. Bottom Five Barriers to Technology integration imposed by Policy and Support Relating them to gender and location.

\section{Conclusion and Future Research}

We investigate barriers that prevent teachers from making effective use of information technology in science education in K-12 public schools in the Yanbu education district in Saudi Arabia. Identifying the fundamental barriers encountered by the science teachers in integrating IT into the classroom is the first step towards a solution to the problem. Two related barriers are greatly limiting which are as follows:

1. No specific budget for IT in school; and

2. Lack of school funds to get hardware. 
These financial barriers could be minimized by providing support and funds from the Ministry of Education and the Yanbu educational district. This study was not the first to identify these barriers. When Al-Mohaissin (1993) applied his study in Saudi Arabia, one of the barriers he identified was the shortage of computers in the schools. This finding is similar to that of Al-Mohaissin (1993) which revealed that funding is not the first problem that needs to be solved. Hendren (2000) declared that the three important factors affecting science teachers' use of technology in the high school classrooms are: lack of access, insufficient funds, and lack of vision. Carter (1998) found that the two most important barriers are lack of computers in the classroom and lack of time to learn how to incorporate IT into the curriculum. Of the five statements least considered as barriers limiting the use of IT into the classroom, all are related to the subdomain of policy and support. School administration is characterized by some participants as being relatively supportive of the effort to integrate technology into the classroom and not perceived as a primary barrier to technology integration. Barriers rooted in policies and funding require a well-conceived, strategic vision, adequate funding, and implementation plan before much change can be expected.

\section{References}

Al-Mohaissin, I. A. (1993). Instructions into secondary school science teaching in Saudi Arabia: Teachers' views, some problems and possible solutions. Doctoral dissertation University of Hull.

Al-Moussa, A. (2004). The integration the information technology to Gulf Cooperation Council (GCC) countries [Electronic version]. Al-Riyadh Newspaper, 22 March 2004.

Al-Oteawi, S. M. (2002). The perceptions of administrators and teachers in utilizing information technology in instruction, administrative work, technology planning and staff development in Saudi Arabia, Doctoral issertation. Ohio University.

Beggs, T. A. (2000). Influences and barriers to the adoption of instructional technology. Paper presented at the fifth annual Mid-South Instructional Technology Conference. Retrieved April 11, 2004, from http://www.mtsu.edu/itconf/ proceed00/beggs/beggs.htm

British Educational Communications \& Technology Department (BECTA). ICT Barriers Survey (2000). Retrieved April 11, 2004 from http://www.becta.org.uk/ research.

British Educational Communications \& Technology Department (BECTA), (2004). What the research says about barriers to the use of ICT in teaching. Retrieved: April 11, 2004, from http://www.becta.org.uk/ page_documents/ research/wtrs_barriersinteach. pdf.

Brush, T. (2003). Preparing tomorrow's teachers to use technology (PT3). Educational Technology Research \& Development, 51(1), 39-128.

Carter, C.W. (1998). An assessment of the status of the diffusion and adoption of computerbased technology in Appalachian college association colleges and universities. Doctoral dissertation, Virginia Polytechnic Institute and State University, Dissertation Abstracts International, 59(10A), 3725.

Corbin, J. F. (2003). The integration of technology into the middle and high school science curriculum, Dissertation Abstracts International. (UMI No. 3081518). 
Ertmer, P. A. (1999). Addressing first- and second-order barriers to change: Strategies for technology integration. Educational Technology Research and Development, 47(4), 47-61.

Hendren, K. (2000). The effect of first and second order barriers on the ideal and actual integration of computer technology into the high science classroom, Dissertation Abstracts International.

Hope, W. (1997). Teachers, computer technology, and the change process. Clearing House, 70(4), 191-93. Retrieved April 12, 2004 from http://science.uniserve.edu. $\mathrm{au} /$ newsletter/vol11/yeo.html.

Mulqueen, W. E. (2001). Technology in the classroom: Lessons learned through professional development. Education, 122(2), 248-256.

National Council for Accreditation of Teacher Education (NCATE). (1997). Technology and the new professional teacher: Preparing for the 21st century classroom. Retrieved May 1, 2004, from http://www.ncate.orglaccreci/projects/ tech/tech-21.htm.

Samman, B. S. (2003). Towards a Successful Implementation of ICT in the Education System of the KSA. Unpublished master's thesis, University of Leeds, UK.

Weber, R. K. (1996). An identification of barriers to the integration of information technology as perceived by secondary education teacher education students, Doctoral dissertation. Georgia State University. UMI

Yeo, S. (1998). Interactive multimedia in secondary Physics classrooms, Curtin University of Technology, UniServe Science News Volume 11. Retrieved May 11, 2004, from http://science.uniserve.edu.au/newsletter/vol11/yeo.html.

Zakaria, Z. (2001). Factors related to information technology implementation in the Malaysian Ministry of Education Polytechnics. Doctoral dissertation. The Virginia Polytechnic Institute and State University. 


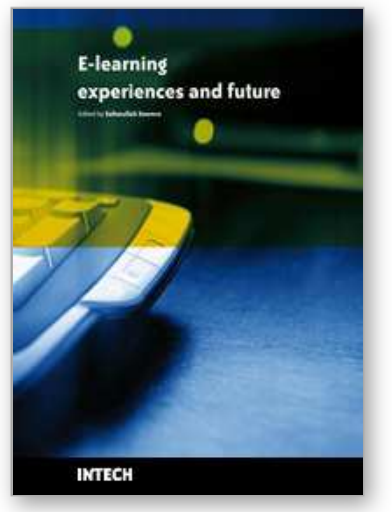

\author{
E-learning Experiences and Future \\ Edited by Safeeullah Soomro
}

ISBN 978-953-307-092-6

Hard cover, 452 pages

Publisher InTech

Published online 01, April, 2010

Published in print edition April, 2010

This book is consisting of 24 chapters which are focusing on the basic and applied research regarding elearning systems. Authors made efforts to provide theoretical as well as practical approaches to solve open problems through their elite research work. This book increases knowledge in the following topics such as elearning, e-Government, Data mining in e-learning based systems, LMS systems, security in e-learning based systems, surveys regarding teachers to use e-learning systems, analysis of intelligent agents using e-learning, assessment methods for e-learning and barriers to use of effective e-learning systems in education. Basically this book is an open platform for creative discussion for future e-learning based systems which are essential to understand for the students, researchers, academic personals and industry related people to enhance their capabilities to capture new ideas and provides valuable solution to an international community.

\title{
How to reference
}

In order to correctly reference this scholarly work, feel free to copy and paste the following:

Abdulkareem Eid S. Alwani and Safeeullah Soomro (2010). Barriers to Effective use of Information Technology in Science Education at Yanbu Kingdom of Saudi Arabia, E-learning Experiences and Future, Safeeullah Soomro (Ed.), ISBN: 978-953-307-092-6, InTech, Available from: http://www.intechopen.com/books/elearning-experiences-and-future/barriers-to-effective-use-of-information-technology-in-science-education-atyanbu-kingdom-of-saudi-a

\section{INTECH}

open science | open minds

\section{InTech Europe}

University Campus STeP Ri

Slavka Krautzeka 83/A

51000 Rijeka, Croatia

Phone: +385 (51) 770447

Fax: +385 (51) 686166

www.intechopen.com

\section{InTech China}

Unit 405, Office Block, Hotel Equatorial Shanghai

No.65, Yan An Road (West), Shanghai, 200040, China

中国上海市延安西路65号上海国际贵都大饭店办公楼 405 单元

Phone: +86-21-62489820

Fax: $+86-21-62489821$ 
(C) 2010 The Author(s). Licensee IntechOpen. This chapter is distributed under the terms of the Creative Commons Attribution-NonCommercialShareAlike-3.0 License, which permits use, distribution and reproduction for non-commercial purposes, provided the original is properly cited and derivative works building on this content are distributed under the same license. 